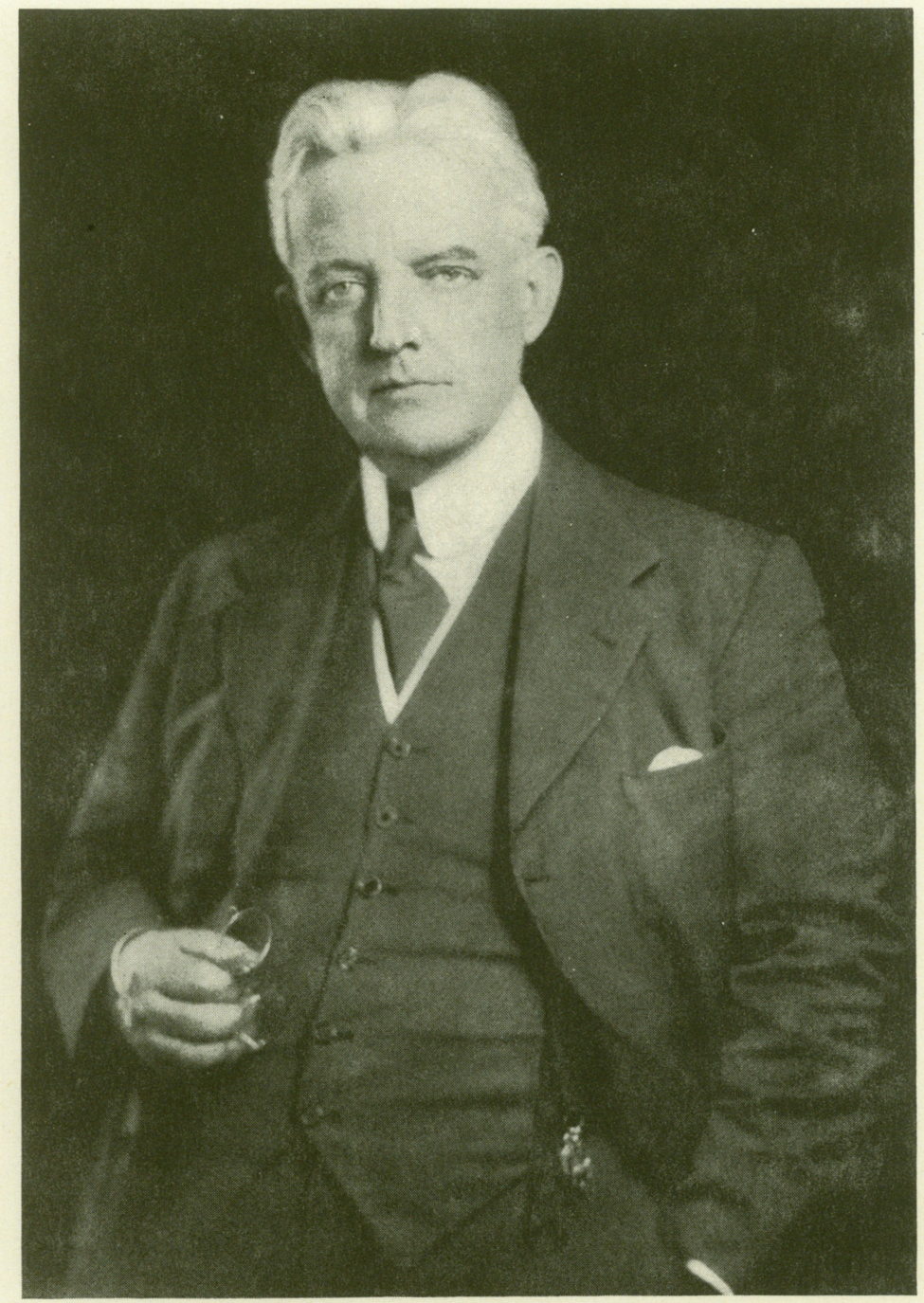

RAYMOND CLARE ARCHIBALD 


\section{Note of Appreciation}

The conception of this quarterly journal, Mathematical Tables and Other Aids to Computation (MTAC) stemmed from the fertile mind of $\mathrm{R}$. C. ARCHIBALD and its establishment was largely due to his initiative and perseverance. As its editor from its first issue in January, 1943, to the close of 1949 , he has given freely of his time and effort. Its success in becoming a useful and often indispensable tool of reference for those concerned with computational problems is due largely to his unflagging interest and untiring efforts in an activity that claimed his well-nigh full-time devotion. The 28 issues published under his editorship will ever stand as a monument to his achievement.

On behalf of the National Research Council, I wish to record its thanks and appreciation to Dr. Archibald for the significant contribution he has made to a field that is of great interest throughout the Council.

As he lays down his editorial responsibilities, his many friends and colleagues extend to Dr. Archibald their warmest felicitations and, with his freedom from "copy deadlines," they wish for him opportunity to spend many years in the pursuit of his avocational interests.

R. C. GibBs, Chairman

Division of Mathematical and Physical Sciences

National Research Council

\section{Raymond Clare Archibald}

Raymond Clare Archibald, Professor of Mathematics, retiring chairman of the Committee on Mathematical Tables and Other Aids to Computadion, 1939-49, founder and editor of Mathematical Tables and Other Aids to Computation of the National Research Council, 1943-49, is well known to the mathematicians of America. Born October 7, 1875 in South Branch, Stewiacke, Colchester County, Nova Scotia, he was a student in Sackville, New Brunswick, at Mt. Allison Academy (1885-89), University (1889-95, A.B. '94), and Ladies' College (1889-95, violin diplomas '94 and '95), where he developed marked ability in mathematics and the violin. He returned to the Ladies' College and from 1900-1907 was Professor of Violin, Harmony, History of Music, and Mathematics, while also serving as Librarian. Between 1895 and 1900 he studied at Harvard, where he received his bachelor's (1896) and master's (1897) degrees, at Berlin, and at the University of Strassburg where he was awarded his doctorate. After a year as Professor of Mathematics and chairman of the department at Acadia University, Professor Archibald came to Brown University in 1908, with which he has been associated ever since and where he is now Professor of Mathematics, Emeritus. He has been appointed delegate to many international congresses, mathematical and of wider scope; he has served as president of the Mathematical Association of America, of which he was a charter member, was twice vice-president of the American Association for the Advancement of Science (for Section A and for Section L respectively); was Librarian of the American 
Mathematical Society 1921-41, member of the executive committee, Division of Mathematical and Physical Sciences of the National Research Council (1941-43) and member of many learned societies, here and abroad. His warm personal friends have included in particular Simon Newcomb, the distinguished astronomer, and M. G. MitTAG-Leffler, of Sweden, one of the leading mathematicians of his day. He has been honored by institutions here and abroad of which may be mentioned Harvard University, Swiss Society of Naturalists, American Academy of Arts and Sciences, Bologna International Congress (1928); Academy of Work in Czecho-Slovakia; Academy of Sciences in Cluj, Rumania; University of Padua; Mathematical Association, England; Polish Mathematical Society. At Brown, in the face of great difficulties he has developed through years of unremitting care and intelligent effort, a Mathematical Library which has been described as "the most useful single source available in America." He has always been active in stimulating undergraduate interest in mathematics. He founded, with $R$. G. D. Richardson and H. P. MANNING, in 1916 and maintained in unbroken continuity an undergraduate Mathematics Club at Brown, and organized and taught courses designed to broaden the appreciation and outlook of prospective teachers of mathematics. There is not room here to list in completeness his 265 numbered published writings, of which some headings cover many separate items. Readers of $M T A C$ need not be reminded of all his contributions to this quarterly. No less intensive was his work for the American Mathematical Monthly, particularly from about 1918 to 1923, largely in connection with geometry, and the history of mathematics (his Outline of the History of Mathematics has come out in sixth edition, 1949). This brief sketch must close with merely a reference to some of the publications in which his work (other than books) has appeared. Educational Times, London; Royal Society of Canada, Transactions; Notes and Queries, London; L'Intermédiare des Mathématiciens; Edinburgh Mathematical Society, Proceedings; American Mathematical Society, Bulletin; Mathematical Gazette; Science; American Mathematical Monthly; National Academy of Sciences, Memoires; Isis; Nature; Congresso Internazionale dei Matematici, Bologna, Atti, 1928; Encyclopaedia Britannica (14th ed.); Dictionary of American Biography; Scripta Mathematica; American Academy of Arts and Sciences, Proceedings; Osiris; Mathematics Teacher; International Congress of Mathematicians, Oslo, Proceedings, 1937. He has also written several books, among them Euclid's Book on Divisions of Figures, published by the Cambridge University Press, 1915. Readers could consult any of twenty biographical sources for information concerning Professor Archibald, of which may be mentioned: American Men of Science; Who's Who in America; Poggendorff (v. 5 and v. 6); Encyclopaedia Britannica (14th ed.).

Albert A. Bennett

Brown University

Providence, R. I. 